\title{
Pathogenic Responses Of Cowpea (Vigna unguiculata) Inoculated With Cucumber Mosaic Virus To Soil Amendment With Neem Leaf Powder
}

\author{
Aliyu, T. H, Balogun, O.S and Adeoti, O.M. \\ Department of crop protection, University of llorin- Nigeria \\ email of Corresponding Author: aliyutaiyehussein@yahoo.com \\ Phone: 234-(0803)-047-2667
}

\begin{abstract}
A study was carried out using potted plants arranged in a randomized complete block experimental design, to evaluate the pathogenic responses of Cowpea that was inoculated with cucumber mosaic virus to soil amendment with neem leaf powder. The amendments were applied at varying rates of $0.125 \mathrm{Kg} / 10 \mathrm{~kg}$ soil, $0.25 \mathrm{Kg} / 10 \mathrm{Kg}$ soil and $0.5 \mathrm{Kg} / 10 \mathrm{Kg}$ soil, and at the time of two weeks before planting, at planting and at two weeks after planting. Plants that served as control were also inoculated with the virus but were sown in soil not amended with neem leaf powder. Results from the experiment indicated that amendment of the soil with neem-leaf powder produced plants that were less vulnerable to diseases occasioned by viruses. The rate and time of the application of the neem leaf powder also appeared to be an important factor in this regard. It was observed that application of relatively lower rate of $0.125 \mathrm{~kg}$ neem leaf powder per $10 \mathrm{~kg}$ of soil at two weeks prior planting conferred the highest tolerance to virus diseases, as these treatment plants had the highest growth indices and yields. On the other hand, plants grown in soil amended at the higher rate of $0.50 \mathrm{~kg}$ neem leaf powder per $10 \mathrm{~kg}$ of soil two weeks after planting, had the lowest growth and yield attributes which were similar to the control. This experiment suggests that neem leaf powder applied as soil amendment at an appropriate rate and time could achieve possible potentials for virus disease control in cowpea.
\end{abstract}

Keywords: Neem leaf powder, Rate and Time of Application, Inoculation, Cucumber mosaic virus, Cowpea, Soil amendment.

\section{Introduction}

Cowpea (Vigna unguiculata L. Walp) a dicotyledonous plant belonging to the order fabaceae, genus Vigna (Cronquist, 1988) is of major importance to the livelihood of millions of people in the tropics (Quin, 1997) . Cowpea diseases induced by species of pathogens belonging to various pathogenic groups constitute one of the most important constraint to profitable cowpea production in all agro- ecological zones where the crop is cultivated (Hampton et al.,1997). Out of more than 20 viruses reported to affect cowpea from different parts of the world, nine are known to infect the crop naturally in Nigeria (Shoyinka et al., 1988). Cucumber mosaic virus (CMV) is a plant virus of the cocumovirus group, infection of a susceptible cowpea leaf results in high virus yields of between 1-2 g/kg (Blum et al., 2005). The symptoms exhibited by virus infected cowpea are 
mosaic, mottling on leaves, necrotic spots on leaves, blisters on leaves, yellow and green vein banding, defoliation, leaf reduction, leaf deformation, witches broom, leaf Chlorosis, apical necrosis, and stunting or plant death (Kareem and Akinjogunla 2008).

Neem is a tropical evergreen tree native to Indian Sub Continent and it is the most researched tree in the world ( Ogbueuu et al., 2011). Every part of the neem tree has been known to possess a wide range of pharmacological properties, and is thus commercially exploitable (Biswas et al., 2002). Meliacin which forms the bitter principles of neem, contains tignic acid (5-methyl-2butanic acid) that is responsible for the distinctive odour (Uko and Kamalu, 2001; Lale, 2002). Neem is therefore a natural source of eco-friendly insecticides, pesticides and agro-chemicals (Brahmachari, 2004).

The current global research efforts now supports the development of plant products with proven crop protection potentials compared to the use of chemicals which may be toxic to both the plants and environment. Faced with limited access to financial resources and coupled with the increasing public awareness on environmental pollution associated with chemical toxicity and residues, this study was undertaken to examine the pathogenic responses of cowpea inoculated with Cucumber Mosaic Virus (CMV) to soil amendments with neem leaf powder at varying rates and different time of application. The objective of the study was to determine the success or otherwise of the amendment in serving as a control measure for viruses.

\section{Experimental design and plant propagation}

\section{MATERIALS AND METHODS}

Pot experiments were conducted in the open pavilion of the Crop Protection Department of the University of Ilorin, Nigeria to evaluate the pathogenic responses of the rate and time of application of dried neem-leaf powder as soil amendment on Cowpea (Vigna unguiculata L.Walp), mechanically inoculated with Cucumber mosaic virus (CMV). The cowpea variety used for the experiment (Cv. Ife-brown) was obtained from the Institute of Agricultural Research and Training, Moor plantation Ibadan. Four seeds were sown per 10 -litre $(50 \mathrm{~cm}$ diameter) plastic buckets filled with sandy-loam soil that was previously steam-sterilized at $121^{\circ} \mathrm{C}$ for 60 minutes and the plants were later thinned to two plants per plastic bucket after germination prior inoculation with the virus. The treatments for the study were the rates of application of neem leaf powder as soil amendment and the time of application of the amendment. The three rates of application were $0.125 \mathrm{~kg} / 10 \mathrm{~kg}$ soil, $0.25 \mathrm{~kg} / 10 \mathrm{~kg}$ soil and $0.50 \mathrm{~kg} / 10 \mathrm{~kg}$ soil, and the time of application was at two weeks before planting (2wksBP), at planting (AP) and at two weeks after planting, (2wks Aft PLT), while the control plants were sown in non amended soil. The amendments were well worked into the soil at two weeks before planting and at planting, while the broadcast method was used at two weeks after planting. This gave 10 treatment combinations replicated 3times each, i.e. 30 plastic buckets of 2 plant stand each. 


\section{Sourcing of inoculum and inoculation procedure}

Cucumber Mosaic Virus isolate was extracted from infected leaves obtained from the stock of the Plant Pathology Laboratory of the International Institute of Tropical Agriculture (IITA) Ibadan, Oyo State Nigeria. The infected leaf sample was extracted by homogenization using mortar and pestle in $0.05 \mathrm{M}$ phosphate buffer, at $\mathrm{pH} 7.2$ at the rate of $1 \mathrm{~g} \mathrm{leaf} \mathrm{sample} \mathrm{to} 5 \mathrm{ml}$ of buffer ( Balogun and Aliyu 2005). All cowpea plants used in the study were inoculated with CMV at 14 days after planting, when the plants were at the $2^{\text {nd }}$ leaf stage. The procedure involved slightly dusting the two primary leaves with carborundum to act as slight abrasive agent, after which the leaves were then rubbed with the extracted juice (CMV virus inoculum), using cotton wool. The plants where then rinsed with water thereafter to reduce inoculation stress (Balogun, 2000).

\section{Data collection}

Data was collected from the $2^{\text {nd }}$ week after inoculation to the $8^{\text {th }}$ week for plant height, number of leaves per plant, number of diseased leaves per plant and the number of pods per plant. The percentage disease severity was measured by the number of diseased leaves relative to the total number of leaves on any given plant.

\section{Harvesting}

The cowpea pods harvested at maturity from each plant at 80-90days after planting were manually threshed and the weights of pods and grains appropriately measured using an electronic weighing balance (Model Kerro No. Ka3002c).

\section{Statistical analysis}

All collected data were subjected to analysis of variance (ANOVA) using the statistical package for the social sciences SPSS version 15.0. The treatment means where significant, were separated using the New Duncan Multiple Range Test at $5 \%$ level of probability (Duncan, 1955).

\section{Effect on percentage disease severity}

\section{RESULTS}

Table 1 showed the results of the treatments on percentage disease severity over 8 weeks. The results showed that plants sown in soils that were amended with neem leaf powder had less diseases compared to the control plants which were also inoculated with the virus but were not amended with neem leaf powder, however the level of disease severity varied significantly. At the $4^{\text {th }}$ week, the treatment combination of $0.125 \mathrm{~kg} / 10 \mathrm{~kg}$ of neem leaf powder applied 2 weeks before planting had the lowest percentage disease severity $(10.3 \%)$, while the rate of $0.50 \mathrm{~kg} / 10 \mathrm{~kg}$ of neem leaf powder applied 2 weeks after planting had a disease severity value of $27.1 \%$, this was not significantly different to applying the rate of $0.25 \mathrm{~kg} / 10 \mathrm{~kg}$ of the amendment at 2 weeks after planting. By the $6^{\text {th }}$ week, percentage disease severity was $57.9 \%$ for application of $0.50 \mathrm{~kg} / 10 \mathrm{~kg}$ of

\section{1}


the amendment at 2 weeks after planting. This same trend was observable till the $8^{\text {th }}$ week, indicating that amendment with $0.125 \mathrm{Kg} / 10 \mathrm{Kg}$ neem leaf powder at 2 weeks before planting gave the significantly lowest percentage disease severity.

\section{Effect on Growth}

Table 2 showed the effect of the treatments on plant heights. The results showed that plants heights were significantly affected by amendment with neem leaf powder as the plants that were amended were taller than the control plants. At the $3^{\text {rd }}$ week, the application of $0.125 \mathrm{~kg} / 10 \mathrm{~kg}$ neem leaf produced the tallest plants $(16.6 \mathrm{~cm})$, the other treatments were not significantly different from each other. This trend was maintained through to the $8^{\text {th }}$ week post inoculation showing that an application rate of $0.25 \mathrm{~kg} / 10 \mathrm{~kg}$ neem leaf powder produced the tallest plants compared with the other treatments. The table also showed that an amendment with neem leaf powder at 2 weeks before planting produced the significantly tallest plants while application at 2 weeks before planting and at planting did not significantly affect plant heights.

Evaluation of the effects of the treatment combination also indicated that there were significant differences. By the $2^{\text {nd }}$ week post inoculation, a rate of $0.125 \mathrm{~kg} / 10 \mathrm{~kg}$ neem leaf powder applied to the soil two weeks before planting, gave the significantly highest plant heights $(17.5 \mathrm{~cm})$. This was followed by an amendment at planting at the rate of $0.125 \mathrm{~kg} / 10 \mathrm{~kg}$ soil $(14.8 \mathrm{~cm})$, while an amendment at planting at the rate of $0.50 \mathrm{~kg} / 10 \mathrm{~kg}$ soil produced the shortest plants $(8.8 \mathrm{~cm})$. This same trend continued from the third through the eighth week post inoculation. It can be observed that from the $2^{\text {nd }}$ to the $8^{\text {th }}$ week post inoculation with the virus, amending the soil at two weeks before planting with the neem leaf powder at the rate of $0.125 \mathrm{~kg} / 10 \mathrm{~kg}$ soil, produced plants, which were significantly taller than the other treatment plants.

\section{Effect on number of leaves}

Table 3 showed the effect of treatment on number of leaves. It can be seen from the table that an application rate of $0.125 \mathrm{~kg} / 10 \mathrm{~kg}$ soil produced the significantly highest number of leaves from the $2^{\text {nd }}$ week through to the $8^{\text {th }}$ week. For instance, by the $5^{\text {th }}$ week post inoculation, an application rate of $0.125 \mathrm{~kg} / 10 \mathrm{~kg}$ soil had plants with the highest number of leaves (16.1), which was significantly different from the other treatments which had similar number of leaves. The effect of time of application of the amendment showed also that an application at two weeks before planting had the significantly highest number of leaves throughout the experimental period. At six weeks post inoculation of the virus, plants amended at two weeks before planting had an average value of 16.1 leaves, compared to an average value of 13.4 leaves and 12.7 leaves for the plants that were amended at 2 weeks after planting and at planting respectively. An analysis of the combined effect of rate and time of application of the amendment on the number of leaves indicates that the plants amended at an application rate of $0.125 \mathrm{~kg} / 10 \mathrm{~kg}$ soil two weeks before planting, had the significantly highest number of leaves compared to the other combinations. 


\section{Effect on yield attributes}

A remarkable variation was recorded for the different treatments for the yield attributes (Table 4). The highest number of total pods per plant (35.2), was obtained in the treatment of amendment with neem leaf powder at the rate of $0.125 \mathrm{~kg} / 10 \mathrm{~kg}$ soil two weeks before planting, which was significantly different from the other treatments. The lowest number of total pods per plant(11.2), was recorded in the treatment with plants that were amended with neem leaf powder at the rate of $0.50 \mathrm{~kg} / 10 \mathrm{~kg}$ soil at two weeks after planting, which was statistically similar to the control (10.6). The different treatments also showed significant differences in weight of pods and the grains. The maximum $(39.3 \mathrm{~g})$ weight of pods and grains $(31.4 \mathrm{~g})$, were recorded for amendment with neem leaf powder at the rate of $0.125 \mathrm{~kg} / 10 \mathrm{~kg}$ soil two weeks before planting. On the other hand, the minimum $(9.1 \mathrm{~g})$ weight of pods and grains $(8.4 \mathrm{~g})$, were recorded with an amendment with neem leaf powder at the rate of $50 \mathrm{~kg} / 10 \mathrm{~kg}$ soil two weeks after planting, the values were similar to that of the control plants $(8.9 \mathrm{~g}$ and $7.8 \mathrm{~g}$ respectively).

\section{Discussion}

In the past two decades, there has been a growing concern on environmental pollution due to the uncontrolled use of synthetic insecticides. The demand for pesticide-free food, the biodegradability of natural products and the greater selectivity of natural products favouring nontarget organisms have encouraged researches in the use of crude, bioactive plant extracts in pest management. One of such plants, which have received international recognition for its pesticidal attributes, is the neem tree, Azadirachta indica (Oparaeke, 2007). The potential of neem products for pest control on crops have been reported by several authors (Jackai et al., 1991; Tanzubil,1991). The complex triterpenoid azadirachtin, obtained from Azadirachta indica, is a potent insect growth regulator and feeding deterrent, with minimal mammalian toxicity and environmental persistence (Isman,2006).

In a study of damage to cotton by the bollworm (Helicoverpa armigera H"ubner) in Benin, it was reported that mixtures of extracts of three local plants Azadirachta indica, Khaya senegalensis, Hyptis suaveolens provided greater efficacy than the conventional inorganic products at their recommended rate (Sinzogan et al.,2006). The incidence and severity of virus diseases is considered to be directly related with availability and abundance of insect vector and depend upon the time of infection (Dhingra and Ghosh, 1993).

This study found that an amendment with neem leaf powder at the rate of $0.125 \mathrm{~kg} / 10 \mathrm{~kg}$ soil two weeks before planting, to be the most effective in reducing the severity of virus diseases in cowpea. It also increased the growth and yield attributes of the plants compared with the control which were not amended with neem leaf powder. These findings are in agreement with the results of other studies showing that plant growth may be affected by virus infection (Guo et al., 2005). It is common for virus infection to have a negative impact on plants by limiting their growth (Wilfert Eckel \&Lampert, 1993; Miteva et al., 2005). It is assumed that the low productivity of the infected cowpea plants is partly as a results of physiological stress that is associated with reduced photosynthesis as a result of infected leaves (Chia \& $\mathrm{He}, 1999)$. 
Vohra and Beniwal (1979) had reported that virus infection affect grain yield when the plants have infection up to 50 days after planting and reduction in yield contributing characters such as pods/ plants, seeds/ pod, 100-seed weight. Sangar et al., (1982), had reported that Azadirachta indica possessed some antiviral compounds active against plant pathogenic viruses, these antiviral compounds are grouped as furocoumarins, alkaloids, terpenoids, lignins, and specific proteins(Zipf 1995). The use of botanicals (rice-husk powder), as an organic amendment to suppress cowpea mottle virus in cowpea had been reported by Aliyu et al.,(2011).

It could therefore be inferred that antiviral compounds in neem leaf was responsible for disease suppression in plants sown in neem leaf amended soil. Application of the amendment at two weeks before planting also had remarkable influence on growth and yield. The findings from this study is in partial agreement with the reports of Katyal and Friescen (1972) and Miah et al. (1990), that extracts from neem leaf if applied early were more effective and had the potential ability in controlling yellow mosaic virus in mungbean.

\section{Conclusion}

It is concluded that neem leaf powder applied two weeks before planting as soil amendment at the rate of $0.125 \mathrm{~kg} / 10 \mathrm{~kg}$ soil is meaningful in ameliorating the effect of pathogenic diseases occasioned by viruses in cowpea. Further research is however suggested in determining the mechanisms by which this is achieved.

\section{Acknowledgement}

The authors will like to express their sincere appreciation to Dr. Lava Kumar of the plant virology unit of the International Institute of Tropical Agriculture (IITA) Ibadan, for providing the viral inoculum used in this study.

Table1: The combination of time and rate of application of Neem-leaf powder as an amendment on Percentage disease Severity on cowpeainoculated with CMV

\begin{tabular}{lllll}
\hline Treatment Combination & 2wks & 4wks & 6wks & 8wks \\
\hline $\begin{array}{l}\text { Control (Inoculated, not } \\
\text { amended) }\end{array}$ & 0 & $34.6 \mathrm{i}$ & $67.3 \mathrm{~h}$ & $73.6 \mathrm{f}$ \\
$2 A P \times 0.125 \mathrm{~kg} / 10 \mathrm{~kg}$ & 0 & $20.8 \mathrm{f}$ & $52.6 \mathrm{fg}$ & $64.3 \mathrm{c}$ \\
$2 B P \times 0.125 \mathrm{~kg} / 10 \mathrm{~kg}$ & 0 & $10.3 \mathrm{a}$ & $24.5 \mathrm{a}$ & $42.3 \mathrm{a}$ \\
AP X $0.125 \mathrm{~kg} / 10 \mathrm{~kg}$ & 0 & $13.5 \mathrm{bc}$ & $42.4 \mathrm{~cd}$ & $58.4 \mathrm{c}$ \\
$2 A P \times 0.25 \mathrm{~kg} / 10 \mathrm{~kg}$ & 0 & $23.5 \mathrm{gh}$ & $54.9 \mathrm{f}$ & $68.7 \mathrm{e}$ \\
$2 B P \times 0.25 \mathrm{~kg} / 10 \mathrm{~kg}$ & 0 & $12.2 \mathrm{~b}$ & $32.1 \mathrm{~b}$ & $51.4 \mathrm{~b}$ \\
AP X0.25k/10kg & 0 & $14.9 \mathrm{c}$ & $44.6 \mathrm{~cd}$ & $59.2 \mathrm{bc}$ \\
$2 A P \times 0.50 \mathrm{~kg} / 10 \mathrm{~kg}$ & 0 & $27.1 \mathrm{~h}$ & $57.9 \mathrm{~g}$ & $72.9 \mathrm{ef}$ \\
$2 B P \times 0.50 \mathrm{~kg} / 10 \mathrm{~kg}$ & 0 & $16.8 \mathrm{de}$ & $38.8 \mathrm{bc}$ & $56.9 \mathrm{~b}$ \\
AP X0.50kg/10kg & 0 & $17.3 \mathrm{ef}$ & $46.2 \mathrm{e}$ & $63.9 \mathrm{c}$ \\
\hline
\end{tabular}

Means within a column followed by the same letter(s) are not significantly different using the New Duncan multiple Range Test at $P>0.05$ 
Table 2: Effect of rate and time of application of Neem leaf powder on plant height $(\mathrm{cm})$ of Cowpea Infected with CMV

\begin{tabular}{|c|c|c|c|c|c|c|c|}
\hline Rate of Application & Wk2 & Wk3 & Wk4 & Wk5 & Wk6 & Wk7 & Wk8 \\
\hline Control & $14.5 \mathrm{a}$ & $15.9 \mathrm{ab}$ & 17.6ab & $17.9 d$ & 23.1ab & $26.4 a$ & $27.7 a b$ \\
\hline $0.125 \mathrm{~kg} / 10 \mathrm{~kg}$ & $14.7 \mathrm{a}$ & $16.6 a$ & $21.9 \mathrm{a}$ & $25.8 \mathrm{a}$ & $33.1 \mathrm{a}$ & $40.5 a$ & $41.2 a b$ \\
\hline $0.250 \mathrm{~kg} / 10 \mathrm{~kg}$ & 14.1a & $15.9 b$ & $18.2 b$ & $19.1 b$ & $28.1 \mathrm{a}$ & $32.4 b$ & $34.4 a$ \\
\hline $0.50 \mathrm{~kg} / 10 \mathrm{~kg}$ soil & $13.3 \mathrm{a}$ & $15.1 b$ & $16.3 b$ & $18.7 \mathrm{c}$ & $25.2 b$ & $28.8 b$ & $31.8 b$ \\
\hline S.E & 0.65 & 0.58 & 0.77 & 11.5 & 1.3 & 0.99 & 1.26 \\
\hline \multicolumn{8}{|l|}{ Time of Application } \\
\hline 2wksAP & $11.9 c$ & $12.5 b$ & $15.4 b$ & $18.9 c$ & $26.4 b$ & $27.9 \mathrm{c}$ & $28.1 \mathrm{C}$ \\
\hline 2wksBP & $14.0 \mathrm{a}$ & $15.1 \mathrm{a}$ & $19.4 a$ & $28.8 a$ & $37.1 \mathrm{a}$ & $38.4 a$ & $39.1 \mathrm{a}$ \\
\hline At planting & $12.8 \mathrm{bc}$ & $13.8 b$ & $16.8 b$ & $25.2 b$ & $26.4 b$ & $29.9 b$ & $30.9 b$ \\
\hline S.E & 0.57 & 0.50 & 0.67 & 9.9 & 1.2 & 0.85 & 1.1 \\
\hline \multicolumn{8}{|l|}{$\begin{array}{l}\text { Time of App. X Rate of } \\
\text { App. }\end{array}$} \\
\hline $2 w k s A P / 0.125 \mathrm{~kg} / 10 \mathrm{~kg}$ & $11.7 \mathrm{c}$ & $12.2 d$ & $13.7 f$ & $21.2 b c$ & $23.8 \mathrm{bcd}$ & $25.8 \mathrm{~cd}$ & $26.1 \mathrm{ef}$ \\
\hline $2 w k s B P / 0.125 \mathrm{~kg} / 10 \mathrm{~kg}$ & $17.5 \mathrm{a}$ & $19.2 a$ & $22.4 a$ & $27.5 a$ & $29.9 a$ & $33.8 \mathrm{ab}$ & $34.6 a$ \\
\hline At plting $/ 0.125 \mathrm{~kg} / 10 \mathrm{~kg}$ & $14.8 b$ & $15.4 b$ & $16.7 \mathrm{de}$ & $19.8 \mathrm{C}$ & $25.8 a b c$ & $28.8 b$ & $29.1 \mathrm{bc}$ \\
\hline $2 w k s A P / 0.25 \mathrm{~kg} / 10 \mathrm{~kg}$ & $11.4 \mathrm{c}$ & $12.8 d$ & $13.5 f$ & $14.5 f$ & $19.1 \mathrm{e}$ & 22.1cde & 24.5efg \\
\hline $2 w k s B P / 0.25 \mathrm{~kg} / 10 \mathrm{~kg}$ & $13.8 \mathrm{bc}$ & $14.2 \mathrm{bc}$ & $19.4 b$ & $20.8 b c$ & $24.7 \mathrm{bcd}$ & $28.7 b$ & $29.7 \mathrm{bc}$ \\
\hline At plting/ $0.25 \mathrm{~kg} / 10 \mathrm{~kg}$ & $11.2 \mathrm{c}$ & $12.9 d$ & 15.9de & $20.9 b c$ & $25.5 a b c$ & $27.5 b c$ & $28.4 \mathrm{~cd}$ \\
\hline 2wksAP/ 0.50kg/10kg & $11.1 \mathrm{c}$ & $13.8 \mathrm{~cd}$ & 14.5ef & 17.5de & 18.4de & $19.4 f$ & $20.0 \mathrm{~h}$ \\
\hline $2 w k s B P / 0.50 \mathrm{~kg} / 10 \mathrm{~kg}$ & $11.1 \mathrm{C}$ & $15.9 b$ & $17.2 \mathrm{~cd}$ & 17.5de & $21.2 \mathrm{cde}$ & $24.2 \mathrm{~cd}$ & 25.2efg \\
\hline At plting $/ 0.50 \mathrm{~kg} / 10 \mathrm{~kg}$ & $8.8 d$ & $9.4 \mathrm{e}$ & $11.4 \mathrm{~g}$ & $16.3 e$ & 23.9ab & $26.9 b c$ & 27.3de \\
\hline
\end{tabular}

Means within a column followed by the same letter(s) are not significantly different using the New Duncan multiple Range Test at $P>0.05$ 
Table 3: Effect of rate and time of application of Neem leaf powder on number of leaves of cowpea Infected with CMV

\begin{tabular}{llllllll}
\hline Rate of Application & Wk 2 & Wk 3 & Wk 4 & Wk 5 & Wk 6 & Wk 7 & Wk 8 \\
& & & & & & & \\
\hline & & & & & & & \\
Control (Inoculated, & $8.1 \mathrm{~b}$ & $8.6 \mathrm{bc}$ & $9.2 \mathrm{~d}$ & $11.6 \mathrm{c}$ & $12.7 \mathrm{c}$ & $14.2 \mathrm{~d}$ & $15.9 \mathrm{~d}$ \\
not amended) & & & & & & & \\
0.125kg/10kg & $9.8 \mathrm{a}$ & $10.1 \mathrm{a}$ & $15.7 \mathrm{a}$ & $16.1 \mathrm{a}$ & $19.7 \mathrm{a}$ & $22.1 \mathrm{a}$ & $23.7 \mathrm{a}$ \\
0.250kg/10kg & $8.8 \mathrm{ab}$ & $9.3 \mathrm{abc}$ & $12.9 \mathrm{~b}$ & $13.4 \mathrm{~b}$ & $16.5 \mathrm{~b}$ & $19.1 \mathrm{~b}$ & $20.5 \mathrm{abc}$ \\
0.50kg/10kg & $8.1 \mathrm{~b}$ & $8.8 \mathrm{bc}$ & $10.6 \mathrm{c}$ & $12.7 \mathrm{~b}$ & $13.1 \mathrm{c}$ & $16.5 \mathrm{bc}$ & $17.4 \mathrm{~cd}$ \\
S.E & 0.43 & 0.61 & 0.80 & 0.85 & 0.54 & 0.89 & 1.28 \\
Time of Application & & & & & & & \\
2wks AP & $8.8 \mathrm{~b}$ & $9.9 \mathrm{~b}$ & $12.1 \mathrm{c}$ & $13.8 \mathrm{c}$ & $14.3 \mathrm{~b}$ & $15.7 \mathrm{~b}$ & $16.2 \mathrm{~b}$ \\
2wks BP & $10.9 \mathrm{a}$ & $11.1 \mathrm{a}$ & $14.7 \mathrm{a}$ & $16.6 \mathrm{a}$ & $18.6 \mathrm{a}$ & $20.6 \mathrm{a}$ & $22.6 \mathrm{a}$ \\
At planting & $9.2 \mathrm{ab}$ & $10.1 \mathrm{ab}$ & $13.3 \mathrm{~b}$ & $14.2 \mathrm{bc}$ & $14.6 \mathrm{~b}$ & $16.5 \mathrm{~b}$ & $19.8 \mathrm{a}$ \\
S.E & 0.37 & 0.53 & 0.69 & 0.73 & 0.74 & 0.77 & 1.1 \\
Rate X Time of & & & & & & & \\
Application & & & & & & & \\
2wksAP/0.125kg/10kg & $6.6 \mathrm{bcd}$ & $18.7 \mathrm{~d}$ & $36.7 \mathrm{bc}$ & $40.7 \mathrm{c}$ & $41.1 \mathrm{c}$ & $42.8 \mathrm{~d}$ & $43.4 \mathrm{c}$ \\
2wksBP/0.125kg/10kg & $10.8 \mathrm{a}$ & $30.1 \mathrm{a}$ & $60.8 \mathrm{a}$ & $62.8 \mathrm{a}$ & $63.5 \mathrm{a}$ & $65.7 \mathrm{a}$ & $66.1 \mathrm{a}$ \\
At pltng/0.125kg/10kg & $8.7 \mathrm{ab}$ & $24.5 \mathrm{c}$ & $48.8 \mathrm{~b}$ & $50.7 \mathrm{~b}$ & $52.1 \mathrm{ab}$ & $53.6 \mathrm{~b}$ & $54.8 \mathrm{~b}$ \\
2wksAP 0.25kg/10kg & $6.3 \mathrm{~cd}$ & $18.8 \mathrm{~d}$ & $36.1 \mathrm{bc}$ & $38.4 \mathrm{~cd}$ & $39.5 \mathrm{~cd}$ & $40.6 \mathrm{~d}$ & $42.8 \mathrm{c}$ \\
2wksBP/0.25kg/10kg & $9.0 \mathrm{a}$ & $23.2 \mathrm{~b}$ & $25.5 \mathrm{~d}$ & $27.7 \mathrm{e}$ & $32.2 \mathrm{e}$ & $36.2 \mathrm{e}$ & $37.1 \mathrm{~d}$ \\
At pltng / 0.25kg/10kg & $8.0 \mathrm{ab}$ & $24.2 \mathrm{c}$ & $48.3 \mathrm{~b}$ & $50.2 \mathrm{~b}$ & $51.5 \mathrm{ab}$ & $51.7 \mathrm{~b}$ & $52.4 \mathrm{~b}$ \\
2wksAP/ 0.50kg/10kg & $6.2 \mathrm{bcd}$ & $18.1 \mathrm{~d}$ & $36.5 \mathrm{bc}$ & $38.0 \mathrm{~d}$ & $41.0 \mathrm{c}$ & $42.6 \mathrm{~d}$ & $44.2 \mathrm{c}$ \\
2wksBP/0.50kg/10kg & $7.0 \mathrm{bc}$ & $21.0 \mathrm{~cd}$ & $42.5 \mathrm{~b}$ & $43.5 \mathrm{bc}$ & $44.7 \mathrm{c}$ & $48.3 \mathrm{bc}$ & $49.3 \mathrm{bc}$ \\
Atpltng/0.50kg/10kg & $7.9 \mathrm{bc}$ & $21.5 \mathrm{~cd}$ & $42.8 \mathrm{~b}$ & $44.8 \mathrm{bc}$ & $45.8 \mathrm{c}$ & $46.6 \mathrm{bcd}$ & $47.4 \mathrm{bc}$ \\
\hline
\end{tabular}

Means within a column ( in each segment) followed by the same letter(s) are not significantly different using the New Duncan Multiple Range Test at $P>0.05$ 
Table 4: The combination of time and rate of application of Neem-leaf powder as an amendment on Yield attributes of cowpeainfected with CMV

\begin{tabular}{llll}
\hline Treatment Combination & $\begin{array}{l}\text { Total no } \\
\text { of pods } \\
\text { per plant }\end{array}$ & $\begin{array}{l}\text { Wt of } \\
\text { pods } \\
\text { per }(\mathrm{g})\end{array}$ & $\begin{array}{l}\text { Weight of } \\
\text { grain }(\mathrm{g})\end{array}$ \\
\hline & & & \\
Control (Inoculated, not & $10.6 \mathrm{i}$ & $8.9 \mathrm{~h}$ & $7.8 \mathrm{i}$ \\
amended) & & & \\
$2 \mathrm{AP} \times 0.125 \mathrm{~kg} / 10 \mathrm{~kg}$ & $14.1 \mathrm{f}$ & $14.9 \mathrm{e}$ & $9.2 \mathrm{~g}$ \\
$2 \mathrm{BP} \times 0.125 \mathrm{~kg} / 10 \mathrm{~kg}$ & $35.2 \mathrm{a}$ & $39.3 \mathrm{a}$ & $31.4 \mathrm{a}$ \\
AP X $0.125 \mathrm{~kg} / 10 \mathrm{~kg}$ & $22.3 \mathrm{~cd}$ & $24.8 \mathrm{~cd}$ & $18.4 \mathrm{c}$ \\
$2 \mathrm{AP} \times 0.25 \mathrm{~kg} / 10 \mathrm{~kg}$ & $13.2 \mathrm{~g}$ & $12.3 \mathrm{f}$ & $8.2 \mathrm{~h}$ \\
$2 \mathrm{BP} \times 0.25 \mathrm{~kg} / 10 \mathrm{~kg}$ & $26.1 \mathrm{bc}$ & $28.6 \mathrm{~b}$ & $21.2 \mathrm{~b}$ \\
AP X $0.25 \mathrm{~kg} / 10 \mathrm{~kg}$ & $18.4 \mathrm{e}$ & $22.5 \mathrm{~d}$ & $16.6 \mathrm{~d}$ \\
$2 \mathrm{APX} 0.50 \mathrm{~kg} / 10 \mathrm{~kg}$ & $11.2 \mathrm{hi}$ & $9.1 \mathrm{gh}$ & $8.4 \mathrm{~h}$ \\
$2 \mathrm{BP} \times 0.50 \mathrm{~kg} / 10 \mathrm{~kg}$ & $18.0 \mathrm{e}$ & $22.2 \mathrm{~d}$ & $14.6 \mathrm{e}$ \\
AP X $0.50 \mathrm{~kg} / 10 \mathrm{~kg}$ & $19.4 \mathrm{de}$ & $14.8 \mathrm{e}$ & $9.4 \mathrm{f}$ \\
\hline
\end{tabular}

Means within a column followed by the same letter(s) are not significantly different using the New Duncan multiple Range Test at $P>0.05$

\section{REFERENCES}

Aliyu, T.H, Balogun, O.S and Alade, 0.0 (2011): Assessment of the effect of rate and time of application of rice-husk powder as an organic amendment on cowpea (Vigna unguiculata L.,walp) inoculated with cowpea mottle virus. Agriculture and Biology Journal of North America 2(1) 74-79.

Balogun, 0.S. (2000). Studies on host-pathogen interactions in tomato under mixed infections with potato $X$ potexvirus and tobacco mosaic tobamovirus. A doctoral dissertation submitted to Tokyo University of Agric and Tech. Japan for the award of Ph.D in Biological Production.Pg1-174.

Balogun, O.S and Aliyu, T.H.(2005). Mechanical transmissibility and pathogenic effect of a mosaic disease of Commelina Benghalensis $L$. in cowpea Vigna unguiculata(L). Journal ofAgric. Resch. \& Dev. 4(2):148-158.

Biswas, K., Chattopadhyay, I., Baerjee, R. K. and Bandyopadhyay, U.(2002). Biological activities and medicinal properties of neem (Azadirachta indica). Curr. Sci. 82(11): 13361345. 
Blum, A.S., Soto C, M., Wilson, C. D., Brower, T. L., Pollack, S.K., Schull, T. L., Chatterji, A., Lin, T., Johnson, J E., Amsinck, C., Franzon, P., Shashidhar, R and Ratna, B . ( 2005). An Engineered Virus as a Scaffold for Three-Dimensional Self-Assembly on the Nanoscale. Small, 7, 702.

Brahmachari, G. (2004). Neem an omnipotent plant. A retrospection. Chem. Biochem, 5: 408421.

Chia T.F and He, J. (1999). Photosynthesis capacity in Oncidium (Orchidaceae) plants after virus eradication. Environmental and Experimental Botany, 42, 1116.

Cronquist , A. (1988). The Evolution and Classification of Flowering Plants 2nd Edition. The New York Botanical Garden, New York, ISBN 0-89327-332-5. Pp. 555.

Duncan, D.B. (1955). Multiple Range and Multiple F test, Biometrics 11:1-42.

Guo, D.P., Guo, Y.P., Zhao, J.P., Liu, H., Peng, Y., Wang, Q.M., Chen, J.S and Rao G.Z. (2005). Photosynthesis rate and chlorophyll fluorescence in leaves of stem mustard (Brassica juncea var. tsatsai) after turnip mosaic virus infection. Plant Science, 168, 5763.

Hampton, R.O., Thottappilly, G. and Rossel. H.W. (1997). Viral diseases of cowpea and their control by resistance-conferring genes. in Advances in cowpea research, edited by B.B. Singh, D.R. Mohan Raj, K.E. Dashiell, and L.E.N. Jackai. Co- publication of International Institute of Tropical Agriculture (IITA) and Japan International Research Center for Agricultural Science (JIRCAS). IITA, Ibadan, Nigeria.159-175

Isman, M B, (2006). Botanical insecticides, deterrents, and repellents in modern agriculture and an increasingly regulated world. Annu Rev Entomol 51:4566.

Jackai, L. E. N and Oyediran, I. O. (1991). The potential of neem, Azadirachta indica A. Juss for controlling post flowering pests of cowpea, Vigna unguiculata (L.) Walp1. The pod borer, Maruca vitrata. Insect Science and its Application 12, 103109.

Kareem, K.T and Akinjogunla O.J. (2008). Proceedings of the third conference on Science and National Development 2008. 102-107.

Katayal, J. C. and Friescen, D. K . (1972). Efficiency of micronutrients and sulphur in wheat production country in tropical environment Proc. 2nd Conf. Held Chiang Mai, Thailand. 
Jan. 19-23, 1987.

Lale, N.E.S. (2002). Bio-activity and Limitation against wide spread use of neem products for the management of Insect pests. Nigeria J. Applied Biol., 3: 115-124.

Miah, A., Ahmed, M. U., Sharma, N. R., Ali, A. and Miah, S. A. (1990). Antifungal activity of some plant extract. Bd. J. Botany. 19 (1):5-20.

Miteva, E., Hristova, D., Nenova, V., Maneva, S. (2005). Arsenic as a factor affecting virus infection in tomato plants: changes in plant growth, peroxidase activity and chloroplast pigments. Scientific Horticulture, 105, 343358.

Ogbuewu, I.P., Odoemenam, V.U., Obikaonu, H.O., Opara, M.N., Emenahom, O.O., Uchegbu, M.C., Okoli, I.C., Esonu, B.O and Iloeje, M.U. (2011). The growing importance of Neem, A.indica in Agriculture, Industry, Medicine and Environment. Research journal of Medicinal plant5 (3): 230-245

Oparaeke A.M. (2007). Acta Phytopathologica et Entomologica Hungarica 42 (1), 153159 DOI: 10.1556/APhyt.42.2007.1.9.

Quin F.M. (1997). Importance of Cowpea in Advances in Cowpea Research. B.B. Singh, K.E. Dashiell, D.R. Mohan Raj and L.E.N. Jackai (Eds.), Pg. X-Xii. Printed by Colcorcraft, Hong Kong, Pp. 375.

Sangar, R. B. S and Dhingra, M. K. (1982). Potato Virus inhibitor from Neem leaf extract. J. Indian PotatoAssoc. 9:143-149).

Shoyinka, S.A., Bozarth, R.F.J. and Rossel, H.W. (1988). Cowpea mottle virus: a seed borne virus with distinctive properties infecting cowpea in Nigeria. Phyto-pathology 68: 693699.

Sinzogan A.A.C., Kossou, D.K., Atachi, P and Van Huis, A. (2006). Participatory evaluation of synthetic and botanical pesticide mixtures for cotton bollworm control. Intl J Trop Insect Sci 26:246255.

Tanzubil, P. B. (1991). Control of some insect pests of cowpea, Vigna unguiculata (L.) Walp with neem, Azadirachta indica (A. Juss) in Northern Ghana. Tropical Pest Management 37, 216217.

Uko, O.J and T.N. Kamalu, (2001). The neem tree uses and potentials. Nig. J. Exptal. Applied Biol, 
2:223- 229.

Vohra, K. and S. P. S. Beniwal(1979). Effect of mungbean yellow mosaic virus on yield and seed quality of urdbean. Seed Research.7(2): 168-174.

Wilfert Eckel R.V and Lampert E.P. (1993). Effect of tobacco etch virus on the seasonal growth of flue-cured tobacco. Crop Protection, 12, 505512.

Zipf, A(1995). Mechanisms of antiviral protein activity in higher plants in Antiviral Proteins in Higher Plants. CRC Press, Boca Raton, FL.. 133-146 